\title{
Prisoners' Access to Justice: Family Support, Prison Legal Education, and Court Proceedings
}

\author{
Elijah Tukwariba Yin ${ }^{1}$, Francis Kofi Korankye-Sakyi ${ }^{1} \&$ Peter Atudiwe Atupare ${ }^{1}$ \\ ${ }^{1}$ University of Cape Coast, Ghana \\ Correspondence: Elijah Tukwariba Yin, Faculty of Law, University of Cape Coast, Ghana. E-mail: \\ elijah.yin@ucc.edu.gh
}

Received: August 2, 2021

Accepted: September 2, 2021

Online Published: September 4, 2021

doi:10.5539/jpl.v14n4p113

URL: https://doi.org/10.5539/jpl.v14n4p113

\begin{abstract}
This study investigates the extent of prisoners' legal entitlements as well as how prisoners acquire legal assistance within the prison setup. It is argued that inmates' legal entitlements within the prison bureaucracy are devoid of the ideal of access to justice. The study used the mixed-method approach in data gathering. For the quantitative aspect, a sample of 300 inmates was used. Simple random and systematic sampling techniques were used to select the respondents. For the qualitative aspect, the following participants were purposively selected: ex-convicts, a paralegal prison officer, a court warrant officer, prison after-care officer, registrars, and relatives of inmates. The analysed data showed that most inmates did not receive family support during their trial before conviction. It was also found that inmates had no access to legal materials due to lack of law libraries, yet received some form of legal education from prison staff. Even though the court proceedings of inmates formed a critical part of their appeal process, a little above half of the inmate population had access to these documents. With the advancement in Information and Communication Technology, it is recommended that all courts should be digitized with relevant logistics and improved infrastructure to smoothen access to case files.
\end{abstract}

Keywords: access to justice, prisoners, court proceedings, family support, legal education

\section{Introduction}

Access to justice and good governance are the pillars of every democratic society. Broadly, the term access to justice, reflecting the tenets of social justice, has been explained to mean a situation where all people, especially the vulnerable group have access to state-sponsored systems of education, legal and welfare services, including health care (Chappelow, 2019; Atuguba, Agyebeng, \& Dedey, 2006). Access to justice has also been defined as state-sanctioned legal services such as having access to legal representation and counselling, legal rights, and legal advocacy services (Atuguba et al., ibid). As expressed in common law, it also involves the right to be heard and the individual's ability to obtain fair and transparent legal services irrespective of social status (Ridge v Baldwin [1964] AC 40; Dimes v Proprietors of Grand Junction Canal [1852] 3 HL Cas 759). In the context of this study, we define access to justice as having equal rights, opportunities, and obligations to access a legal institution for its functions in a fair, transparent, and equitable manner, especially for the illiterate, the poor, and the vulnerable in society. The United Nations and the Rule of Law report (2019) reveals that the lack of access to justice impedes the exercise of rights, promotes discrimination, and silences the voices of minorities and the marginalised.

The critical need for access to justice as a right is not only grounded in Chapter 5 of Ghana's 1992 constitution but also the Universal Declaration of Human Rights (UDHR), the African Charter on Human and Peoples Rights (ACHPR), and the United Nations Declaration on the Right to Development (UNDRTD). The common aim of all these legal instruments is to protect human dignity and rights, promote equality and equity, and advance the rule of law and justice. The Voluntary National Review Report by the Government of Ghana (2019) on the implementation of the 2030 Agenda for Sustainable Development states that the Commission on Human Rights and Administrative Justice (CHRAJ) was established to promote this agenda following the Paris Principles. Goal 16 of the UN 2030 agenda for sustainable development finds its roots in the mobilisation of all these legal instruments. This makes the case for access to justice not only important to Ghana but also the international community.

Despite its relevance, there are many bottlenecks characterising access to justice in Ghana. This includes the high cost of legal services, the difficulty of accessing justice by the poor and vulnerable - prisoners, children, and 
women (Atuguba et al., 2006; UNDP, n.d.), the absence of public legal education, and the complexity of adjudication. For this work, we will focus on prisoners, not because they are more vulnerable but because less attention has been paid to them on this matter. Particularly, on the support they receive from family members during their trial, education on their legal rights/entitlements by the prison service, and the extent to which access to court proceedings is facilitated. In the context of this work, court proceedings refer to the totality of court documents such as a charge sheet, documented exchanges during the trial, and the judgement/ruling of the court.

There are some scholarly interventions in the area of access to justice (see Rhode, 2000, 2004; Cappelletti, Garth, Weisner, Koch, 1978; Vargo, 1992; Francioni, 2007, 2009; Wizner \& Aiken, 2004; Cabral, Chavan, Clarke, \& Greacen, 2012; Albiston \& Sandefur, 2013; Sternlight, 2011; Davis, Erez, Avitabile, 2001). Ghana has received its share of such interventions (see Atuguba et al., 2006; Crook, 2004; Adu-Gyamfi, 2014; Nolan-Haley, 2015; Morhe, 2010; Atua, 2013; Frimpong, 2017; Riggs, 2012). These studies have contributed significantly to the literature on access to justice in various ways. However, their focus suggests the rareness of studies in the area of prisoners' access to justice. That is, the family support extended during the trial, the role of the prison in educating prisoners on their legal rights, as well as how prisoners acquire their court proceedings.

Prisoners are a vulnerable group of people. Their confinement makes them forfeit most of their rights as human beings, yet they are entitled to legal rights such as the right to legal materials (Bounds v. Smith, 430 U.S. 817 [1977]), legal counsel (Article 14(2) of Ghana's 1992 Constitution), court and court proceedings, and fair justice delivery (Yin et al., 2021). As a common law principle, in R v Secretary of State for the Home Department ex p Leech (No 2) [1994] QB 198, Steyn LJ held at 210A that: "It is a principle of our law that every citizen has a right of unimpeded access to a court." In R v Lord Chancellor exp Witham [1998] QB 575, Laws J argued that "the common law affords special protection to the right of access to a court as a constitutional right." All these form the basis of inmates' legal rights. However, preliminary investigations within some major prisons in Ghana (Ankaful Prisons Complex, Kumasi Central Prison, Nsawam Medium Security Prison, Sekondi Prison, etc.) reveal the void between the ideal of access to justice and practice. For instance, many inmates do not have access to their court proceedings - a legal requirement for appeal, hence are unable to access the court. They are, in effect, serving sentences deemed unfair which is an affront to justice, and an abuse of their fundamental human rights. It is for this reason that an investigation into the extent of prisoners' legal entitlements as well as how prisoners acquire legal assistance is warranted. The study will address this research question: How do prisoners access their legal entitlements within their state of confinement? It is argued that inmates' legal entitlement within the prison bureaucracy is devoid of the ideal of access to justice.

Studying prisoners' access to justice in itself demonstrate a gap between the law and prisoners. Access to justice is an important symbol, and its pursuit is a call for legal responsiveness and reform (Korankye-Sakyi, 2021; Atupare, 2021). Not limited to only social or justice reform but an essential political tool "from which strategic bargaining advantages may flow" (Crossman \& Sarat, 1981, p. 125). Evidence suggest that access to justice promotes government accountability, sustainable growth, security and inclusive development. Meeting the justice and legal needs of prisoners is a way of addressing everyday legal problems (OECD, 2016).

\section{Method}

There are forty-three (43) prisons in Ghana. Among the establishments is hierarchically the Prisons Headquarters in the capital city of Ghana, Accra. It is the administrative centre of the service where prison policies are formulated for effective management of all prison establishments in Ghana. In the headquarters are the Director-General of Prisons and his two deputies, five Directors of Prisons, and other principal officeholders. There are seven (7) Central Prisons, seven (7) Female Prisons, fourteen (14) Local Prisons, one (1) Medium Security Prison at Nsawam, and eleven (11) open and Agricultural Settlement Camp prisons. There is one (1) Maximum Security Prison, one (1) juvenile facility, and one (1) special facility. There is one Prison Officers Training School (POTS) in Accra and the Accra Senior Correctional Centre (ASCC: formerly called Ghana Borstal Institution) purposefully for character education and socio-religious development of juvenile offenders.

As of 2018, the total prison population was 14,467. For this study, the following prisons were used as data collection centres: Nsawam Medium Security Prison (NMSP), Ankaful Annex Prison, Kumasi Central Prison, and Sekondi Prison. The former and the latter prisons were useful because they house both male and female prisoners. Like these two aforementioned prisons, Ankaful Annex and Kumasi Central prisons also house remand and convicted prisoners. NMSP had the highest number of prisoners in Ghana. The selected prisons for this study house both high profile and long sentence prisoners with different demographic characteristics. These categories of prisoners reflect the general prison population in Ghana. As a result, gathering data from inmates on access to justice aided to address the research question as well as contributed meaningfully to our understanding of the 
subject matter.

The method of data gathering was informed by both the positivist and interpretivist philosophy. That is quantitative and qualitative approaches. The mixed-method approach was used because it provides researchers with the opportunity to view issues from different perspectives (Creswell \& Clark, 2017; Neuman, 2007). The quantitative data offer a broader view whilst the qualitative data offer in-depth information as well as an experiential account. Basically, the qualitative narratives explain the rationale behind the numbers.

The source of data was primary empirical. The primary empirical data was generated through in-depth interviews and the administration of semi-structured questionnaires. These data sources validated each other. Some common law principles established through case laws were also used to contextualise and stretch our analysis. Though the case laws are not of Ghanaian jurisprudence, we share that they have some persuasive effects and have both theoretical and practical significance for our study.

For the quantitative aspect of this work, the units of analysis were solely convicted inmates and remand prisoners. A semi-structured questionnaire was designed to solicit the views of inmates on how they acquired legal assistance. The advantages associated with this type of instrument are that it is quick and flexible for respondents and interviewers. It facilitates the conduct of the interview as well as offers high response rates. Aside from this, the inmates were already in a state of captivity; volunteering for an interview is often just another opportunity to engage with a seemingly concerned outsider or a visiting staff. Despite the usefulness of the semi-structured questionnaire, it was time-consuming and exhaustive.

Considering the nature of the study environment, a quota of 300 was assigned as the sample size. This approach of sample determination is accepted for a study associated with a closed population and within a regimental confinement (Sedgwick, 2012). This sample size was distributed proportionately across the four prisons and in relation to the gender composition. Simple random and systematic sampling procedures were used to select the inmates. The first respondent was selected based on the lottery method (the number 4 was selected), after which the interval of four was used to systematically select the other respondents based on the list of inmates provided by the prison. This sampling approach was used across the selected prisons. The sample size aided a broader view of the situation studied. See Table 1 on the distribution of samples across selected prisons.

Table 1. Sample distribution across selected prisons

\begin{tabular}{lllll}
\hline Prison & Convicted & Remand Prisoners & Male & Female \\
\hline Nsawam Prison & 100 & & 70 & 30 \\
Kumasi Central & 40 & 20 & 60 & \\
Ankaful Annex & 40 & 20 & 60 & \\
Sekondi Prison & 80 & & 60 & 20 \\
Total & $\mathbf{2 6 0}$ & $\mathbf{4 0}$ & $\mathbf{2 5 0}$ & $\mathbf{5 0}$ \\
& & $\mathbf{3 0 0}$ & & $\mathbf{3 0 0}$ \\
\hline
\end{tabular}

For the qualitative aspect of this work, the following persons were purposively selected: 10 inmates (6 males and 4 females), 1 paralegal prison officer, 1 court warrant officer, 8 ex-convicts, 1 prison after-care officer, 7 significant others (relatives of inmates), and 2 court registrars. These participants were selected to participate in the study due to their strategic position, experience, and information they have to offer so far as family support and the legal needs of prisoners were concerned. The interviews were aided by the use of an interview guide. The advantage associated with this approach was that it allowed participants to express themselves freely and in a way that the use of a questionnaire could not have permitted.

The quantitative data was analysed using the Statistical Package for the Social Sciences (SPSS) version 22 whilst the transcripts of in-depth interviews were coded based on themes and patterns for manual analysis. After the qualitative data analysis, a validation exercise was carried out that allowed participants and other actors to share their views on the data gathered. This ensured that the analysed data reflected the views of the participants.

According to Neuman $(2007$, p. 54) "a fundamental ethical principle of social research is: Never coerce anyone into participating; participation must be voluntary at all times. Permission alone is not enough; people need to know what they are being asked to participate in so that they can make an informed decision. Participants can become aware of their rights and what they are getting involved in when they read and sign a statement giving 
informed consent". In this research, participants were not coerced into participation. Participation was purely voluntary. Participant's consent was sought by signing a consent form before data was gathered.

Respondents/participants were assured of their privacy, confidentiality, and anonymity while making the research results available. Their identities were not disclosed after information gathering (Alderson \& Morrow, 2020; Sales \& Folkman, 2000). Pseudo names were used instead of their real names. Neuman (2007, p. 49) states that "a researcher's authority to conduct social research and to earn the trust of others is accompanied always by an unyielding ethical responsibility to guide, protect, and oversee the interests of the people being studied".

The inmates were informed that this research was not going to reduce their sentence. It was not going to benefit them in any way for now but could be significant for policy making to improve the weak areas in the justice system. No cash payments or promises were made, and no favours asked were granted to inmates. Inmates were also made aware that by participating in the research they may learn things about the justice system they may not have known, and that the conversational interviews offer an opportunity for them to ask questions they may have about the justice system. This encouraged inmates to participate in the study, and at best informed them to be truthful about the information they give out for the study. Ethical clearance was sought from the ethics committee of the University of Cape Coast.

\section{Inmates Views on Family Support, Prison Legal Education, and Court Proceedings in Accessing Justice}

The criminal justice system is aimed to offer justice as well as protect all members of society through the conviction, punishment, and rehabilitation of the offender. The investigation and arrest, pretrial activity, adjudication, sentence, and corrections are all steps in the criminal justice process. With these defined steps, access to justice or justice delivery is considered a process. As a result, it was important to find out from respondents about the support they received from their family members during their trial which spanned between the time of arrest and conviction. The survey data show that $68.6 \%$ of inmates did not receive any family support between the time of arrest and conviction, $18.7 \%$ of inmates said their families hired the services of lawyers for them, whilst $18.7 \%$ of inmates also said their families were present in court to encourage and witness the trial processes.

This data corroborates with what was said by some participants during the in-depth interview. According to a female prisoner;

It was a sad process, yet my family never gave up on me. They were always present in court until I was finally jailed.

An ex-convict added that;

I had massive support from my family. There was no court day that my mother and sister were not present.

Whilst some inmates acknowledged and praised the role of their families during the trial process, other inmates said otherwise. A male prisoner stated that;

None of my family members showed up during the trial process. I was neglected by them.

This position was reiterated by an ex-convict;

Kw3333" (expression of surprise), which family? They (family) never showed up in court. Since my 7 years in prison, they have not even visited me.

For why most family members did not show up during the trial, it was explained in terms of the cost associated with going to court and hiring a lawyer. An interviewed family member said;

I have to work to earn money for the family. If I have to go to court or hire a lawyer, it all required money.

Another significant other added;

I cannot spend the time I have to work to attend court. How do I feed the rest of the family? ...not that I don't want to but the financial means are lacking. Travelling that far and sleeping over will be a huge financial burden to bear.

Time, they say, is money (Franklin, 1748; Chayka, 2017). For family members without a pool of financial reserve to draw on in times of emergency, it is understandable that they would be unable to spend money and time attending court hearings. In instances where the prosecuting court is a distance away, it requires that family members have 
the money to travel and book a hotel to spend the required days for the court hearing. This, it appears is unaffordable to most family members, hence their inability to show up during the trial proceedings of their arrested kin.

On whether those who received some form of family support during the trial considered it as sufficient, $50.9 \%$ of inmates did not regard such support as sufficient whilst $49.1 \%$ said the support was sufficient. In respect of why it was sufficient, $43(78.2 \%)$ said not every family will support their son/daughter with a lawyer after engaging in crime, whilst $12(21.8 \%)$ said the presence of their families was very encouraging.

Those who got some form of family support but considered it as not sufficient gave the following reasons: 30 $(52.6 \%)$ said it was not all the time that their families were present to witness the court trial, $21(36.8 \%)$ said their family members did not visit them on remand, whilst $6(10.6 \%)$ said their families could not pay the court fine imposed on them. During the in-depth interviews, two participants stated as thus;

Sometimes they (family) showed up in court to witness proceedings but were most often absent. (Pat, female inmate, 2021).

According to a response by another inmate;

If my family hires a lawyer for me but does not show up in court it gives a bad signal to the judge. So far as they were absent I cannot consider their support as sufficient.

Family support, or lack thereof, is to be seen in context. The presence of family members in court suggests that the offender is cherished or loved by them. Or maybe considered as a good member of the family. This could also mean that the family wants to reengage and ensure the proper socialisation of the offender. In contrast, the absence of family support during trial could mean that the offender is an unwanted family member who is a known deviant.

For family members who attend court hearings, it is a costly affair that they could offer. For others, a day or two off work is cost-prohibitive; even more so retaining a lawyer. Even among inmates who received family support during their trial, most of them considered such assistance insufficient. This was explained based on a family's inability to pay a court fine, hire a lawyer, as well as their absence during the trial. For those who had lawyers yet considered the absence of family members in court as a shortfall reveal the psycho-social needs of people standing trial. The data show that criminal trials could bring about distress and hardship on families - considering that some family members would have to forgo their economic means to attend a criminal trial of their relative. As Dennis (2017) found, the criminal trial of a person impacts family life, socially and economically. Notwithstanding, some inmates comprehend why their family members did not attend their court hearing. Family members may be very conscious of their deviant status by association with the criminal. This is consistent with Goffman's (1960) stigmatisation by association. Neuberg, Smith, Hoffman, and Russell (1994) shared that people are stigmatised due to their association with a stigmatised person. The data infer that there is little social and economic comfort in attending a hearing about a family member whose flawed character may be well known. Whether family support or not, it is common knowledge that a person found guilty of a criminal offence is made to serve a corresponding period of imprisonment or pay a fine.

The imprisonment of a person behooves some responsibility on prison authorities as defined by law. In Ghana, the prisons service is mandated to do the following: ensure the safe custody of prisoners and execution of sentences in a humane manner; ensure the welfare of prisoners through the protection of their rights and providing them with good health care, clothing, bedding, feeding, recreation, and library facilities, among other amenities; and finally ensure the reformation and rehabilitation of prisoners by offering them opportunities to develop their skills through trade-training and moral education (Ghana Prison Service, 2013; Yin, 2018; Yin, 2020). Obviously, the second mandate includes the education of convicted persons on their legal rights as well as the provision of legal libraries to augment the legal knowledge of inmates to access the courts as espoused in Bounds v Smith (1977). That, to guarantee convicted criminals' right to meaningful access to the courts, prison officials must offer law libraries or legal help to prisoners. This is consistent with article $208(3)(\mathrm{k})$ of Ghana's 1992 Constitution which stipulates that "such measures, generally as will ensure the humane treatment and welfare of prisoners and other persons in legal custody, including the provision of literature and writing material" shall be part of the regulations to be included for the purposes of clause (2) of article 208. This right of access to the legal system and materials serves as the foundation for judicial recognition and preservation of all of a prisoner's constitutional rights (Jacobs, 1983).

In Lindquist v Idaho State Board of Corrections (1985, p. 855), the Court of Appeals for the Ninth Circuit emphasised, "a prison must provide inmates with access to an adequate law library, or in the alternative, with adequate assistance from persons trained in the law". The provision of law libraries and legal assistance 
encapsulate the education of inmates on their legal rights. A legal right is any interest recognised and guarded by law. Against this background, it was essential to find out from inmates whether the prison service had a law library and whether they were educated on their legal rights after conviction. In respect of the availability of law libraries, it came out from the interviews that there was no prison in Ghana that had a library dedicated to law. However, there were few other libraries purposely to improve the literacy level of inmates. It was therefore not surprising that $286(95.3 \%)$ of inmates said they had no access to legal materials such as books, journals and commentaries which discuss the law, encyclopedias and dictionaries which provide an overview and background on a topic, relevant reports of parliamentary committees, explanatory memorandum, law reform reports, and parliamentary debates. Nonetheless, 14 (4.7\%) of inmates said they had access to legal materials such as sample motions and grounds of appeal.

Having access or not to legal materials might not necessarily correlate with the education of inmates on their legal rights by the prison. The survey data on the education of inmates on their legal rights revealed that $266(88.7 \%)$ of inmates admitted they had such education after conviction whilst $34(11.3 \%)$ said otherwise. The availability of law libraries and the legal education of inmates are two important components that promote access to justice. Whilst the data show the unavailability of law libraries in prison, it however points to a very important step of legal education by the prison - that is, the education of inmates on their rights to appeal a dissatisfactory legal outcome due to faulty legal ruling, inadequate evidence or disregarded alibi. This implies that although the prison may be deficient in some respect, yet their knowledgeable staff do not relent of their efforts when their functions are purposive and consequential within their mandates.

On how such prison legal education was carried out, 170 (63.9\%) of inmates said it was done through prison social workers and counsellors, $78(29.3 \%)$ said they were educated by other inmates, whilst $18(6.8 \%)$ said they were educated by lawyers who represented them in court. This was confirmed during the in-depth interview as a male prisoner said;

After my conviction and was brought to prison, the prison counsellor and social worker organised a counselling session for me and other inmates who had just been convicted. Through the counselling process, we were told of our right to appeal our sentences if we were not satisfied with the decision of the court. (Kwesi, Male prisoner)

Another inmate reiterated that;

It was a routine activity of the prison to assemble all newly convicted prisoners to educate them on their right to a lawyer and of appeal. (Atongo, Male prisoner)

This education was not only done by social workers and prison counsellors but also by other inmates. This was revealed by an inmate who said;

...all the knowledge I have on my legal rights and appeal were from other inmates through regular conversations. ...sometimes through our prison "mock court" trials.

Even if rudimentary, it is worth noting that inmates do have some level of knowledge about their legal rights, and an understanding of the justice system in Ghana. Within various prisons, it is not unusual to find sessions where inmates hold informal mock court trials for fellow inmates. The sessions end with suggestions by seasoned inmates claiming to "know the system", offering advice, and suggestions on how inmates with pending trials can improve their odds. This finding is consistent with the work of Akonor (2021), that inmates held "Toli" (informal meeting) sessions to informally discuss their various court trials.

Not all inmates consented to been educated on their legal rights, however, such inmates were aware of such rights. In the interview process, such inmates were asked how they became aware of such rights. A participant attributed the knowledge acquisition to the observation of the activities of some inmates by stating that;

I was in the same cell with an inmate who wrote motions for other inmates to initiate their appeal process. Whilst there, I observed and learnt from him. I also asked questions whenever necessary.

Whilst other inmates observed and became knowledgeable of their legal rights, an inmate said;

I have no idea of such rights. No one has educated me on the appeal process. I see some inmates holding papers but hardly do I understand what they are 
about.

The data reveal the critical role played by the prison service through the prison social workers and counsellors in promoting prisoners' access to justice. The challenges faced by prisons, particularly in Africa, are enormous, hence one can interpret the unavailability of law libraries as not a priority, maybe, for now. This is against the constitutional provision in Bounds $\mathrm{v}$ Smith. The decision in Bounds did not require education programmes to ensure effective utilization of legal materials, however, this was rather ongoing as the study found. This was one of the ways through which inmates improved their means of making use of the process that protect their rights as incarcerated citizens. This finding concurs with that of Smith (1987), that prison legal education programmes helped improve the effectiveness of inmates in accessing justice as well as protect their constitutional rights.

In the United States ex rel. Mayberry v. Prasse, the court held that prisoners' access to justice included "the right of a prisoner to prepare, serve, and file legal papers and prosecute legal actions affecting his personal liberty". That prisoners could not be restrained from effectively prosecuting their appeal. For a prisoner to prepare, file, and prosecute a legal action in court, it requires some supporting legal documents such as the prisoner's court proceedings. Inmates share that before they could file a motion in court, it was a requirement for them to acquire their court proceedings in support of the motion as well as evidence for their grounds of appeal. The empirical data reveal that $174(58 \%)$ of prisoners had access to their court proceedings whilst $126(42 \%)$ said they did not have their court proceedings. This means that, even though the court proceedings were a necessary requirement to initiate an appeal, not all inmates had access to such important legal requisite.

In respect of how they got their court proceedings, 92 (59.9\%) said they applied for their proceedings through the prison after-care officer, 37 (21.3\%) said their families went for the proceedings on their behalf, 31 (17.8\%) applied for it through prison officers, $12(6.9 \%)$ said they were assisted by an NGO to acquire their court proceedings, whilst $2(1.1 \%)$ said they applied for their proceedings through friends.

During the in-depth interview, the prison after-care officer stated that;

I have applied for court proceedings for many inmates. It is part of my responsibilities as a social worker. ...it was necessary because sometimes the court of conviction is far from the prison where the inmate is serving his/her time.

A family member who was interviewed also stated that;

The court of conviction was not far from where I lived so when my brother told me he needed his court proceedings, I did not hesitate to go for it.

From the data, after-care agents, family members, prison officers, and friends were the conduits through which inmates got their court proceedings. Predominantly were the after-care agents and family members. It is useful to state that, the after-care agents are the liaison officers between the prison inmates and the outside community. Their role in inmates' access to justice appears crucial as revealed in the data. The data also show the support received by inmates through families and friends. Irrespective of the deviant status of inmates, for some family members and friends, keeping in touch was a way of maintaining meaningful familial and social relationships with their deviant kin. Against the backdrop that almost half of the inmates did not have their court proceedings at the time of data collection, it was necessary to ask questions that bordered on duration, and the costs of court proceedings. See Figure 1 on the duration it took inmates to get their proceedings. 


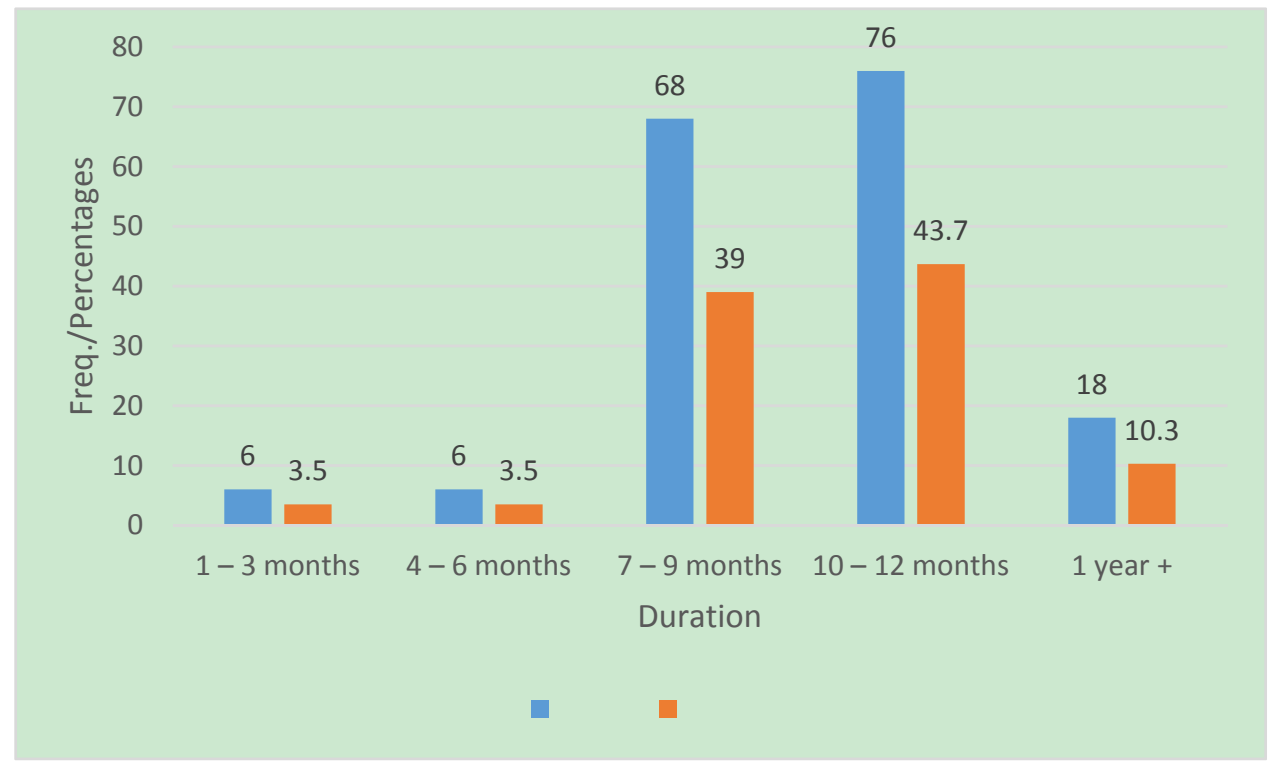

Figure 1. Duration to accessing court proceedings

Source: Fieldwork, 2021

Figure 1 shows that it took 76 (43.7\%) of inmates between 10 to 12 months to get their proceedings, 68 (39\%) said it took between 7 to 9 months, $18(10.3 \%)$ said it took over a year, $6(3.5 \%)$ said it took between 4 to 6 months, whilst $6(3.5 \%)$ also said it took 1 to 3 months before they got their proceedings from the court of conviction.

An inmate stated that;

Proceedings don't come easy. It takes many months to get it. For some inmates, it took them over a year. The delay is unacceptable.

One would be able to know if these durations represent a delay in acquiring court proceedings or not if it is compared with a kind of standard period within which proceedings are made ready. In a discussion with a court registrar, it was said that;

The court has no standardized period within which proceedings are to be produced to the applicant.

The claim made by inmates about the delay in getting their court proceedings was explained by the registrar;

I agree that sometimes it takes a long period before proceedings are prepared. This may not be our fault. In this court, there is only one typist who works on the proceedings. The applications are many and it is based on first come first served.

The registrar added that;

...some of the trial processes spanned over three years. This means the typist would have to type out all that ensued in court for that period. It is not an easy job. The typist has other responsibilities aside from typing proceedings. Let me also add that, there were instances our computer broke down and we had to halt all typing-related jobs until it was fixed. At times, there is nothing that can be done about the delay.

Adding on to the challenges, the registrar said;

They've been times the court did not have a printer to print. Look, as I speak to you (interviewer) we do not have papers to print. What do you expect with challenges like this?

Even though the registrar explained the delay in terms of logistics, inmates attributed the delay to monetary payment. An inmate explained that;

...the truth is that the more you pay for your proceedings, the earlier you get 
it.

An ex-convict added that;

...the court will give you good explanations for their delay, but put GHS3000 on their desk and ask them to produce the court proceedings in 1 week. You will be amazed.

This necessitated the need to know how much inmates paid for their court proceedings. Table 2 below shows how much inmates paid for their proceedings.

Table 2. Cost of court proceedings

\begin{tabular}{lll}
\hline How much did you pay for it? (GHS) & Frequency & Percentage \\
\hline $100-300$ & & \\
$400-600$ & 3 & 1.7 \\
$700-900$ & 5 & 2.9 \\
$1000-1200$ & 88 & 50.6 \\
$1200+$ & 78 & 44.8 \\
& $\mathbf{1 7 4}$ & $\mathbf{1 0 0}$ \\
\hline
\end{tabular}

Source: Fieldwork, 2021

The survey research shows that $88(50.6 \%)$ of inmates paid between GHS1000 to GHS1200 to get their court proceedings, 78 (44.8\%) paid over GHS1200, 5 (2.9\%) paid between GHS700 to GHS900, whilst 3 (1.7\%) paid between GHS400 to GHS600 to get their court proceedings.

During the in-depth interviews, an ex-convict stated that;

It was very expensive to get my court proceedings. I paid about GHS1600 before I got my court proceedings. ...I can say some people spend more than this amount to get their proceedings.

A male inmate added that;

If you do not pay, forget your court proceedings. It does not come free. You don't get a receipt for any payment.

The data show the challenges faced by both inmates and the court. Inmates attribute the delay in getting their proceedings to the corrupt and extortive nature of court staff whilst court staff also attribute the delay to institutional constraints such as lack of logistics - computers, printers, papers, and the lack of administrative remedy. Inmates' claim of corruption in the court finds support in the 2020 Afrobarometer survey by the Center for Democratic Development in Ghana that court officials are widely seen as corrupt and untrustworthy. The report further revealed that more than 8 in 10 Ghanaians (85\%) say at least "some" judges and magistrates are corrupt, including $40 \%$ who said almost all court officials are corrupt. The data is as well consistent with Agbemava (2018) that court staff extort money from court users. Notwithstanding these allegations of corruption, the reality of multiple challenges facing the court cannot be overlooked. The challenges expressed by the court registrar also find defence in the available literature. Asamoah (2021) found that most courts in Ghana lacked adequate logistics and stationary to carry out their functions. These findings also find succor in Agbemava (2018) that the court lacked quality support staff due to its' inability to attract the best brains. That, most typists or recorders could hardly type or spell a word which made it difficult for them to type fast in order to keep up with court procedures.

From the data, the pursuit of justice (appeals) is expensive for the poor and illiterate inmates. Even for the educated and salaried workers, having to spend GHS1000 on accessing court documents is nothing short of a major drain on the household budget. For some inmates, the cost is affordable largely as a result of relatives and friends, and in some cases the inmates contributing the money needed to access the court documents.

It was not all about cost. To other inmates, it was the case that their proceedings could not be traced. An inmate said that;

I applied through the after-care officer for my court proceedings. He came back to tell me the court says they cannot trace my court proceedings. 
Another inmate said that;

When I applied for my proceedings, I was told the judge who sentenced me got sick and died. And that he took with him the book that contained my proceedings. The court has written to me officially indicating my proceedings cannot be traced.

The case of not being able to trace court proceedings was reiterated by another inmate who said that;

I was told the court got flooded after a rainstorm. ...the floodwater carried some documents away. Unfortunately, it included some recorded books that contained information on my court proceedings.

Not being able to pay for the cost of court proceedings is one thing whilst not being able to access such documents due to their unavailability at the court is also another thing. In one instance, the court official passed away, and the document of the inmate was never found. In another instance, the court was flooded due to heavy rain. Morton (2016) captured the latter situation as "many court buildings are in a bad state, the infrastructure are not suitable for occupation by court officials. In some remote areas, Magistrates are unable to sit when it rains because the roofs leak." These data reveal the dilapidated state of some court facilities in Ghana. It is therefore not surprising that some inmates have lost their court proceedings to flooding. These situations deny not only inmates access to justice but also other court users. All these challenges espoused by inmates, ex-convicts, and the court registrars reveal that inmates' access to justice is devoid of the ideal of access to justice which entails putting up the necessary structures to facilitate judicial procedures.

The lack of family support, accessing legal materials, the cost associated with acquiring court proceedings, and the challenges facing the courts pervade inmates' access to justice. While this is a major concern, at the heart of the matter is the lack of Legal Aid Services for persons evaluated to qualify for government-funded legal representation. Legal Aid is in its infancy in Ghana and is generally underfunded (Attu, 2019). All these impede the exercise of rights and promote discrimination. Likewise, the United Nations and the Rule of Law report (2019) indicate that lack of access to justice is an abuse of human rights, discriminatory, as well as silences the voices of the marginalized. Atuguba et al (2006) also shared that access to justice is characterised by difficulties such as the high cost of legal services. As revealed in this study, inmates would have to pay for the transportation cost of the social worker, pay for the court proceedings itself, as well as incur the cost of hiring a lawyer (if needed). All these make the case of access to justice difficult for most inmates.

\section{Conclusion}

This study looked into the extent of inmates' legal entitlements/rights as well as how they obtained legal assistance while incarcerated. The study addressed this research question: How do convicts access their legal entitlements while incarcerated? We argued that inmates' legal entitlements are bereft of the ideal of access to justice. For data collection and analysis, a mixed-method approach was utilized. Inmates, both males and females, paralegal prison officers, court warrant officers, ex-convicts, prison after-care officers, court registrars, and some relatives made up the unit of analysis.

The analysed data revealed that most inmates did not receive family support during their trial before conviction. Inmates categorised the support to mean the presence of family members in court and hiring of the services of lawyers. Family members saw this as a costly affair as it meant that they would have to forego their economic sustenance to support a deviant member whose activities may have brought shame to the entire family. Even among inmates who received family support, some considered such support insufficient.

On the availability of legal materials - such as law books/law libraries and the education of inmates on their legal rights, law libraries were totally absent in all the prisons in Ghana. It was therefore not surprising that inmates had no access to legal materials to improve their legal knowledge. The absence of law libraries did not mean the prison had no libraries at all. In fact, there were some forms of libraries but were to improve the literacy levels of inmates.

It is clear that most inmates, do have a general understanding of their rights to access the justice system from behind the bar. They are aware that being sentenced to prison does not deny them access to justice in order to appeal their cases on merit. Two significant ways inmates acquire their knowledge: a) informal-learning from fellow inmates; and b) formal — orientation sessions organised for new prisoners about their rights to appeal the court outcome.

Prison staff, namely Social Workers and Counsellors, serve a major function in providing basic legal education to inmates to know their legal right to appeal their cases. Peer-to-Peer tutorials by jailhouse lawyers are present in all the prisons. These are not qualified lawyers, yet they exhibit knowledge about the criminal justice procedures, and 
to some extent provide fellow inmates with an inexpensive way to write their appeal.

Legal proceedings are critical to appealing one's case. While a little above $50 \%$ of prisoners with financial resources, and the social network of family and friends were able to access the court proceedings, the same cannot be said for inmates whose files were declared missing or destroyed in a flood. This is a case of institutional inefficiency with detrimental consequences for inmates. This is particularly harmful to inmates on remand whose cases are held in abeyance because there is no way to get representation without documentation.

The digitalisation of court proceedings is long overdue in Ghana. With the advancement in Information and Communication Technology, all courts should be digitised or automated to smoothen access to case files. The delays and distress in accessing one's legal proceeding to mount a merited defence in and of itself amount to the violation of inmates' human rights.

\section{References}

Adetula, V. A. O. (2011). Measuring democracy and 'good governance' in Africa: A critique of assumptions and methods. In K. Kondlo, \& C. Ejiogu (Eds.), Governance in the 21st century. South Africa: HSRC Press.

Adu-Gyamfi, E. (2014). Challenges undermining domestic violence victims' access to justice in Mampong municipality of Ghana. Journal of Law, Policy \& Globalization, 27, 75.

Agbemava, S. (2021). Civil Court Staff in Ghana: Working Conditions and Legal Training for an Effective Procedure. Retrieved from https://www.nomos-elibrary.de/10.5771/2363-6262-2018-1-102/civil-court-staffin-ghana-working-conditions-and-legal-training-for-an-effective-procedure-volume-5-2018-issue-1?page=1 on $24 / 08 / 2020$

Akonor, E. T., \& Obeng, A. S. (2021). Conducting Research in Ghana's Prisons: Recounting Administrative and Ethical Dilemmas. In Yin, E. T., \& Kofie, N. (Eds.), Contemporary Issues on Criminology in Africa. New York: Nova Science Publishers.

Albiston, C. R., \& Sandefur, R. L. (2013). Expanding the empirical study of access to justice. Wisconsin Law Review, 101.

Alderson, P., \& Morrow, V. (2020). The ethics of research with children and young people. A practical handbook: SAGE Publications Limited.

Asamoah, J. M. (2021). Juvenile Justice Administration in Ghana. Retrieved from https://scholarworks.waldenu.edu/cgi/viewcontent.cgi?article=11186\&context=dissertations on 07/05/2021

Attu, R. (2019). The National Legal Aid Scheme in Ghana: A Problem in Search of a Solution. https://doi.org/10.2139/ssrn.3422809

Atua, K. A. (2013). Alternative Dispute Resolution and its Implications for Women's Access to Justice in AfricaCase-Study of Ghana. Frontiers of Legal Research, 1(1), 36-57.

Atuguba, R., Agyebeng, K., \& Dedey, E. (2006). Access to justice in Ghana: The real issues. A Research Report Prepared for Civic Foundation and the United Nations Development Programme (UNDP). Retrieved from https://ladagroupgh.com/docs/5854320d48f0ed75317469e0d04679eeAccess\%20to\%20Justice\%20In\%20G hana\%20-\%20The\%20Real\%20Issues.pdf on 04/09/2020

Atupare, P. A. (2021). A fundamental law of reason and the constitutional law of elections in Africa. Journal of Comparative Law in Africa, 8(1), 1-41. https://doi.org/10.47348/JCLA/v8/i1a1

Bounds v. Smith, 430 U.S. 817 (1977).

Cabral, J. E., Chavan, A., Clarke, T. M., \& Greacen, J. (2012). Using technology to enhance access to justice. Harvard Journal of Law \& Technology, 26, 241.

Cappelletti, M., Garth, B. G., Weisner, J., \& Koch, K. F. (1978). Access to Justice, 4: Brill.

Center for Democratic Development (2020). Afrobarometer Report. Retrieved from https://afrobarometer.org/sites/default/files/press-

release/Ghana/gh_r8_pr_highcost_bias_delays_prevent_ghanaians_from_using_justice_system_28022020. pdf on $20 / 05 / 2021$

Chappelow, J. (2019). Social Justice. Investopedia. Retrieved from https://www.investopedia.com/terms/s/socialjustice.asp on 03/09/2020

Chayka, K. (2017). Time is Money. But that doesn't mean you need to work non-stop. Pacific Standard. 
Creswell, J. W., \& Clark, V. L. P. (2017). Designing and conducting mixed methods research. Sage publications.

Crook, R. C. (2004). Access to justice and land disputes in Ghana's state courts: The litigants' perspective. The Journal of Legal Pluralism and Unofficial Law, 36(50), 1-28. https://doi.org/10.1080/07329113.2004.10756576

Crossman, J. B., \& Sarat, A. (1981). Access to justice and the limits of law. Law and Policy Quarterly, 3(2), 125140. https://doi.org/10.1111/j.1467-9930.1981.tb00239.x

Dimes v Proprietors of Grand Junction Canal (1852) 3 HL Cas 759.

Francioni, F. (2009). Access to justice, denial of justice and international investment law. European Journal of International Law, 20(3), 729-747. https://doi.org/10.1093/ejil/chp057

Franklin, B. (1748). Advice to a Young Tradesman. University of Virginia Press.

Frimpong, A. B. (2017). Using technology for access to justice in Ghana and Canada: Examining the digital divide. University of Saskatchewan.

Fusch, P. I., \& Ness, L. R. (2015). Are we there yet? Data saturation in qualitative research. The qualitative report, 20(9), 1408. https://doi.org/10.46743/2160-3715/2015.2281

Ghana Prison Service. (2013). Prisons Annual Report.

Goffman, E. (1963). Stigma: Notes on the Management of Spoiled Identity. Prentice-Hall, New Jersey.

Government of Ghana (2019). Voluntary National Review Report on the Implementation of the 2030 Agenda for Sustainable Development. Retrieved from https://sustainabledevelopment.un.org/content/documents/23420Ghanas_VNR_report_Final.pdf on 05/09/2020

Jacobs, J. B. (1983). New Perspectives on Prisons and Imprisonment. New York: Cornell University Press.

Korankye-Sakyi, F. K. (2021). The civil justice reform debate: An African perspective. In Yin, E. T., \& Kofie, N. (Eds.), Advancing Civil Justice Reform and Conflict Resolution in Africa and Asia: Comparative Analyses and Case Studies (pp. 46-62). New York: IGI Global. https://doi.org/10.4018/978-1-7998-7898-8.ch003

Lindquist v Idaho State Board of Corrections (1985, p. 855).

Morhe, R. A. S. (2010). Access to Justice and Resolution of Criminal Cases at Informal Chiefs' Courts: The Ewe of Ghana. Stanford University.

Neuberg, S. L., Smith, D. M., Hoffman, J. C., \& Russell, F. J. (1994). When we observe stigmatized and "normal" individuals interacting: Stigma by association. Personality and Social Psychology Bulletin, 20, 196-209. https://doi.org/10.1177/0146167294202007

Neuman, D. J. (1958). Research Interviewing in Prison. Journal of Criminal Law and Criminology, 49(2). https://doi.org/10.2307/1140922

Neuman, W. L. (2006). Social research methods: Qualitative and Quantitative Approaches. Boston: Allyn and Bacon.

Neuman, W. L. (2007). Basics of Social Research Qualitative and Quantitative Approaches. Allyn and Bacon, Boston.

Nolan-Haley, J. (2015). Mediation and access to justice in Africa: Perspectives from Ghana. Harvard Negotiation Law Review, 21, 59.

OCED. (2016). Understanding effective access to justice. Retrieved from https://www.oecd.org/gov/Understanding-effective-access-justice-workshop-paper-final.pdf on 06/08/2021

R v Lord Chancellor exp Witham [1998] QB 575.

R v Secretary of State for the Home Department ex p Leech (No 2) [1994] QB 198.

Rhode, D. L. (2000). Access to justice. Fordham Law Review, 69, 1785.

Rhode, D. L. (2003). Access to justice: Connecting principles to practice. Geo. J. Legal Ethics, 17, 369.

Rhode, D. L. (2004). Access to justice. Oxford University Press.

Ridge v Baldwin [1964] AC 40.

Riggs, E. (2012). Internship: Providing access to justice in Ghana. Bulletin (Law Society of South Australia), 34(1), 
19

Sales, B. D., \& Folkman, S. E. (2000). Ethics in research with human participants. American Psychological Association.

Sedgwick, P. (2012). Proportional quota sampling. BMJ, 345, e6336. https://doi.org/10.1136/bmj.e6336

Smith, C. E. (1987). Legal Education in Prisons: Special Problems and Opportunities for Correctional Education. Journal of Correctional Education, 34(4).

Sternlight, J. R. (2011). Tsunami: AT\&T Mobility LLC v Concepcion Impedes Access to Justice. Oregon Law Review, 90, 703.

Strauss, A. L., \& Corbin, J. M. (1998). Basics of qualitative research: Techniques and procedures for developing grounded theory. California: Sage.

United Nations and the Rule of Law report. (2019). Access to Justice. Retrieved from https://www.un.org/ruleoflaw/thematic-areas/access-to-justice-and-rule-of-law-institutions/access-to-justice/ $30 / 08 / 2020$

United Nations Development Project. (n.d.). Justice now within the reach of the poor and vulnerable in Ghana. Retrieved

from

https://www.gh.undp.org/content/ghana/en/home/ourwork/democraticgovernance/successstories/justicewithin-the-reach-of-the-poor-in-ghana--.html on 01/09/2020

United States Ex Rel. Mayberry v. Prasse, 225 F. Supp. 752.

Vargo, J. F. (1992). The American Rule on Attorney Fee Allocation: The Injured Person's Access to Justice. American University Law Review, 42, 1567.

Wizner, S., \& Aiken, J. (2004). Teaching and Doing: The role of law school clinics in enhancing access to justice. Fordham Law Review, 73, 997.

Yin, E. T. (2018). Religion as an Organising Principle in Ankaful Maximum Security Prison, Published Doctoral Thesis, University of Cape Coast.

Yin, E. T. (2020). Religion, rehabilitation and reintegration of inmates into mainstream society. In A. Balloni, \& R. Sette (Eds.), Handbook of Research on Trends and Issues in Crime Prevention, Rehabilitation, and Victim Support (pp. 398-414). IGI Global. https://doi.org/10.4018/978-1-7998-1286-9.ch023

Yin, E. T., Atupare, P. A., Kofie, N., Owusu, L. P., \& Botchway, T. P. (2021). Rights and religious belief in maintaining prison social order. UCC Faculty of Law Journal, 1(1).

1992 Constitution of the Republic of Ghana. Accra: Assembly Press.

\section{Copyrights}

Copyright for this article is retained by the author(s), with first publication rights granted to the journal.

This is an open-access article distributed under the terms and conditions of the Creative Commons Attribution license (http://creativecommons.org/licenses/by/4.0/). 